\title{
Ricerca interdisciplinare e ICAR I7: una proposta per la definizione di un modello condiviso
}

\author{
Alessandro Luigini
}

\section{Abstract}

Lo scopo di questo paper è di riportare i risultati di alcuni studi internazionali che hanno trattato il tema della valutazione della ricerca interdisciplinare, per poi declinare le osservazioni di carattere generale sulla disciplina del Disegno, come definito dal corpus della produzione scientifica degli studiosi afferenti a questa area, prendendo come campione le pubblicazioni di due Convegni Internazionali dei Docenti delle Discipline della Rappresentazione tenutisi a Milano nel 2018 e a Perugia nel 20I9. Inoltre, si proporrà un possibile modello di studio - di natura statistica - per le tendenze interdisciplinari del settore disciplinare a partire da valutazioni di ordine generale dedotte dall'osservazione delle keywords dei contributi ai convegni UID del 2018 e 2019.

Parole chiave

interdisciplinarità, disegno, eteronomia, disparità disciplinare.

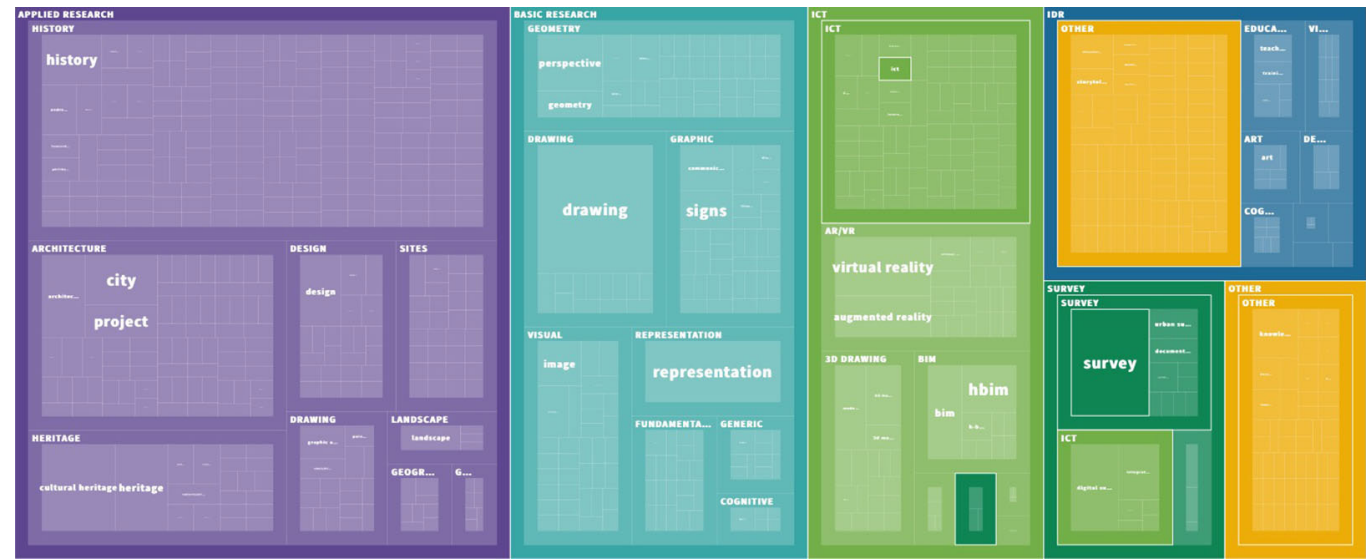




\section{Introduzione}

Trattare il tema della ricerca interdisciplinare è sempre stimolante perché probabilmente più adeguato al paradigma contemporaneo del progresso del Sapere, e perché consente di guardare al di là dei confini disciplinari, tenendo i piedi saldi all'interno dello spazio noto e solido della disciplina, ma interpretando i confini disciplinari come un confine di riferimento e non come un limite.

Com'è chiaro ai più, il settore scientifico disciplinare ICAR I7 Disegno è un settore eterogeneo, in parte eteronomo, che si è sviluppato grazie alla confluenza di Saperi derivanti dalle Hard Science e dalle Humanities, come è stato ricordato nel $2^{\circ}$ Seminario sulla valutazione della ricerca tenutosi presso il Dipartimento di Storia, Disegno e Restauro dell'Architettura di Sapienza-Università di Roma lo scorso 4 marzo [I]. Questa eterogeneità, come in tanti altri casi, è una opportunità ma anche una fonte di rischio.

Il presente contributo mira a trattare - brevemente, per ragioni di spazio - il tema della ricerca interdisciplinare facendo riflessioni terminologiche, metodologiche, di dominio e di osservazione dello stato dell'arte, per poi proporre una possibile metodologia di valutazione dell'impatto della ricerca interdisciplinare nel nostro settore scientifico disciplinare.

\section{Definizioni}

Le consuete esigenze di chiarezza della scrittura scientifica, ci impongono di partire dal chiarimento di cosa si intende per 'interdisciplinarità' e per altri modelli a esso limitrofi e occasionalmente utilizzati - licenziosamente - come sinonimi.

I termini che definiscono la ricerca che si distanzia dalla ricerca disciplinare sono: 'pluri- o multidisciplinare', 'interdisciplinare' e 'transdisciplinare', a cui si aggiunge 'crossdisciplinare'.

a) Pluri- o multidisciplinare. Nel campo della ricerca, si parla di attività pluri- o multidisciplinare quando "si utilizzano teorie, metodi e standard interpretativi delle diverse discipline. L'interpretazione dei risultati delle diverse discipline avviene tipicamente post hoc, spesso dal punto di vista di una disciplina che può emergere come dominante all'interno del progetto" [Rossini, Porter 1979]. In questo contesto, quindi, le discipline concorrono insieme allo sviluppo del progetto, ognuno con il proprio specifico impianto metodologico ed epistemologico, con una gerarchia tra disciplina dominante e discipline partecipanti.

b) Interdisciplinare. Diverso è il caso del termine interdisciplinare, che definisce la ricerca in cui "gli approcci integrano dati, metodi, strumenti, concetti e teorie disciplinari separati per creare una visione olistica o una comprensione comune di una questione, una domanda o un problema complesso" [Wagner et al. 201 I, p. 16].

La visione olistica richiamata in questa definizione ci ricorda come la complessità non sia governabile da modelli semplici e, senza abbandonarsi alla sperimentazione incontrollata di modelli non convenzionali, è necessario formulare risposte complesse - o multiple - per rispondere a domande altrettanto complesse.

c) Transdisciplinare. In letteratura si intende transdisciplinare la "ricerca transettoriale, orientata ai problemi, che coinvolge una più ampia gamma di stakeholder nella società" [Klein 2008, p. SI 17]. Questa definizione apre ulteriori questioni da dibattere, che in questa sede per esigenze di brevità ci limitiamo a sottolineare: la ricerca transdisciplinare non solo tende a travalicare le frontiere delle discipline, ma si rivolge a un'ampia gamma di stakeholders e, quindi, a una molteplicità di istanze da tenere in considerazione.

d) Cross disciplinare. II termine crossdisciplinare, più semplicemente "è spesso usato per descrivere le tre modalità di ricerca sopra definite" [Davè et al. 20 I6, p. I3].

Negli ultimi decenni la frequenza del termine interdisciplinare e di altri a esso affini che abbiamo trattato nel paragrafo precedente, è andata aumentando con un trend positivo. Molti studi dimostrano che la interdisciplinarità è spesso indicata come uno dei fattori che contribuiscono alla promozione dell'innovazione [Gibbons et al. 1994] e della creatività [Jacobs, Frickel 2009] anche perché più efficace per la ricerca di soluzioni a problemi complessi [Page 2007, p. 16], perché capace di mettere in discussione convinzioni consolidate [Barry et 
al. 2008] e di alimentare la creatività [Heinze et al. 2009; Hemlin et al. 2004]. Ma nonostante queste premesse altri studi dimostrano che la ricerca interdisciplinare è percepita come uno svantaggio quando si entra nel processo di valutazione [Rinia et al. 200 la, p. 357; Nightingale, Scott 2007, pp. 546, 547] e in alcuni casi si è dimostrato, su base qualitativa, che la revisione tra pari è spesso influenzata negativamente dalla interdisciplinarità [Laudel, Origgi 2006; Langfeldt 2006, p. 3I].

Uno stimolante studio, da cui abbiamo tratto molti spunti e una buona parte delle letture effettuate per scrivere queste pagine, analizza su base quantitativa i meccanismi di disincentivazione della ricerca interdisciplinare in alcuni contesti della ricerca in campo economico in Gran Bretagna [Rafols et al. 20 I2]. Gli autori dimostrano per la prima volta il pregiudizio nei confronti della ricerca interdisciplinare su base quantitativa e che tale pregiudizio può osservarsi non solo in occasione della revisione tra pari ma anche nelle valutazioni considerate meno soggette alla variabilità di giudizio di un revisore, come nel caso delle classificazioni delle riviste o nel caso di sistemi di valutazione della ricerca, in Gran Bretagna denominato REF - Research Excellence Framework, analogamente alla classificazione delle riviste scientifiche e di classe A dell'ANVUR e alla nostra VQR - Valutazione della Qualità della Ricerca. In questa prospettiva gli autori esaminano i tre principali ambiti di valutazione che ruotano attorno alle pubblicazioni scientifiche: la classificazione delle riviste, la revisione tra pari e la valutazione della qualità della ricerca.

La prima critica mossa da Rafols e gli altri autori è alla ristretta selezione di indicatori utilizzati per la valutazione, in alcuni casi un unico indicatore bibliometrico, ovvero l'indicatore citazionale. Secondo diversi altri studi [Martin, Irvine 1983; Stirling 2010 ] l'utilizzo di un certo numero di indicatori parziali è più adeguato alla valutazione di concetti multidimensionali come, ad esempio, l'interdisciplinarità [Rafols et al. 20 I2, p. I263].

Questo quadro avverso allo sviluppo della ricerca interdisciplinare è, però, criticato da alcune osservazioni di carattere metodologico: la ricerca interdisciplinare è spesso additata come "propensa al rischio", fondata su basi non del tutto solide dal punto di vista disciplinare [Bruce et al. 2004] e occasionalmente si presenta il rischio che l'interdisciplinarità sia solo uno dei fattori a cui si deve la rilevanza di una ricerca, e non necessariamente tra i più determinanti [Rafols et al. 20I2, p. 1264].

Tutto questo insieme di criticità ha come effetto un rallentamento dello sviluppo di reti interdisciplinari, anche per le scarse prospettive di carriera per i ricercatori propensi alla ricerca interdisciplinare e la ulteriore difficoltà a pubblicare su riviste prestigiose [Bruce et al. 2004, p. 464]. E stato anche dimostrato che le ricerche interdisciplinari trovano più spazio in riviste con minore impatto citazionale rispetto le ricerche strettamente disciplinari [Rinia et al. 200 I a p. 360; Rinia et al. 200 Ib, p. 247] e che la ricerca interdisciplinare ha meno possibilità di essere finanziata da programmi nazionali di finanziamento alla ricerca [Bromham et al. 20।6].

\section{Metodologia}

La circoscritta review della letteratura scientifica in materia di valutazione della ricerca interdisciplinare, ci fornisce una base su cui impostare una osservazione, di natura prevalentemente qualitativa ma su basi quantitative, dello stato dell'arte per quanto concerne la ricerca interdisciplinare nel nostro settore scientifico disciplinare, utile - in un approfondimento successivo a questa stesura - a fornire riferimenti condivisi per la valutazione della ricerca interdisciplinare.

Lungi dall'essere esaustivo, questo studio pone le basi per una riflessione condivisa concentrando la propria attenzione ad alcuni metadati per l'indicizzazione, ossia le 'keywords'.

Sono stati presi in esame i proceedings degli ultimi due Convegni Internazionali dei Docenti delle Discipline della Rappresentazione, tenutisi a Milano nel 2018 e a Perugia nel 2019. I temi dei convegni sono stati: Rappresentare/materiale/immateriale. Drawing as (in)tangible representation [Salerno 20 I 8] per il convegno tenutosi a Milano nel 20 I 8, e Riflessioni, l'arte del disegno | il disegno dell'arte [Belardi 2019] per il convegno tenutosi a Perugia nel 2019.1 
contributi presi in esame sono quelli in lingua inglese.

Le keywords di tutti i contributi sono state inserite in un dataset per l'elaborazione quantitativa, per un totale di 1289 elementi che delineano un ampio soggettario degli interessi sviluppati nel nostro settore disciplinare. Le keywords sono state successivamente 'uniformate' e 'aggregate: 'uniformate', perché i dati sono risultati fin da subito non sufficientemente 'nitidi', presentando numerose declinazioni di temi particolarmente diffusi (es: 3D model, 3D models, 3D modeling), mantenendo le quali avrebbero necessariamente alterato le analisi, e aggregate perché la grande variabilità delle keywords, anche dopo la loro uniformazione, non avrebbe consentito una lettura significativa della frequenza di ambiti e temi disciplinari. Questo processo, centrale nella impostazione di questo lavoro, necessita un ulteriore approfondimento metodologico, oltre a un ampliamento del campione che ci si pone come prospettiva futura.

\section{Aggregazione successive in cluster}

Il data set è stato organizzato su tre livelli: il più esterno (fig. I) è il livello che contiene tutte le keyword uniformate; il livello intermedio indica il macro-tema a cui ogni singola keyword viene stabilito facciano riferimento (architecture, design, landscape, geography, site, history, heritage, survey, ICT, BIM, drawing, geometry, graphic, visual, cognitive, basis, generic, education, other); il livello più interno invece indica alcuni cluster (basic research, applied research, survey, ICT, IDR, other), che vengono assegnati alla singola keyword e non ai macro-temi. Quest'ultima precisazione implica che due keywords appartenenti allo stesso macro-tema possono appartenere a due cluster differenti (es: la keyword visual culture fa parte del macro-tema visual e del cluster basic research, la keyword screen fa parte sempre del macro-tema visual ma del cluster IDR).

Si sottolinea subito come questo insieme non sia del tutto omogeneo, dato che molti casi - se non la quasi totalità - delle keywords riconducibili a ricerca applicata possano essere

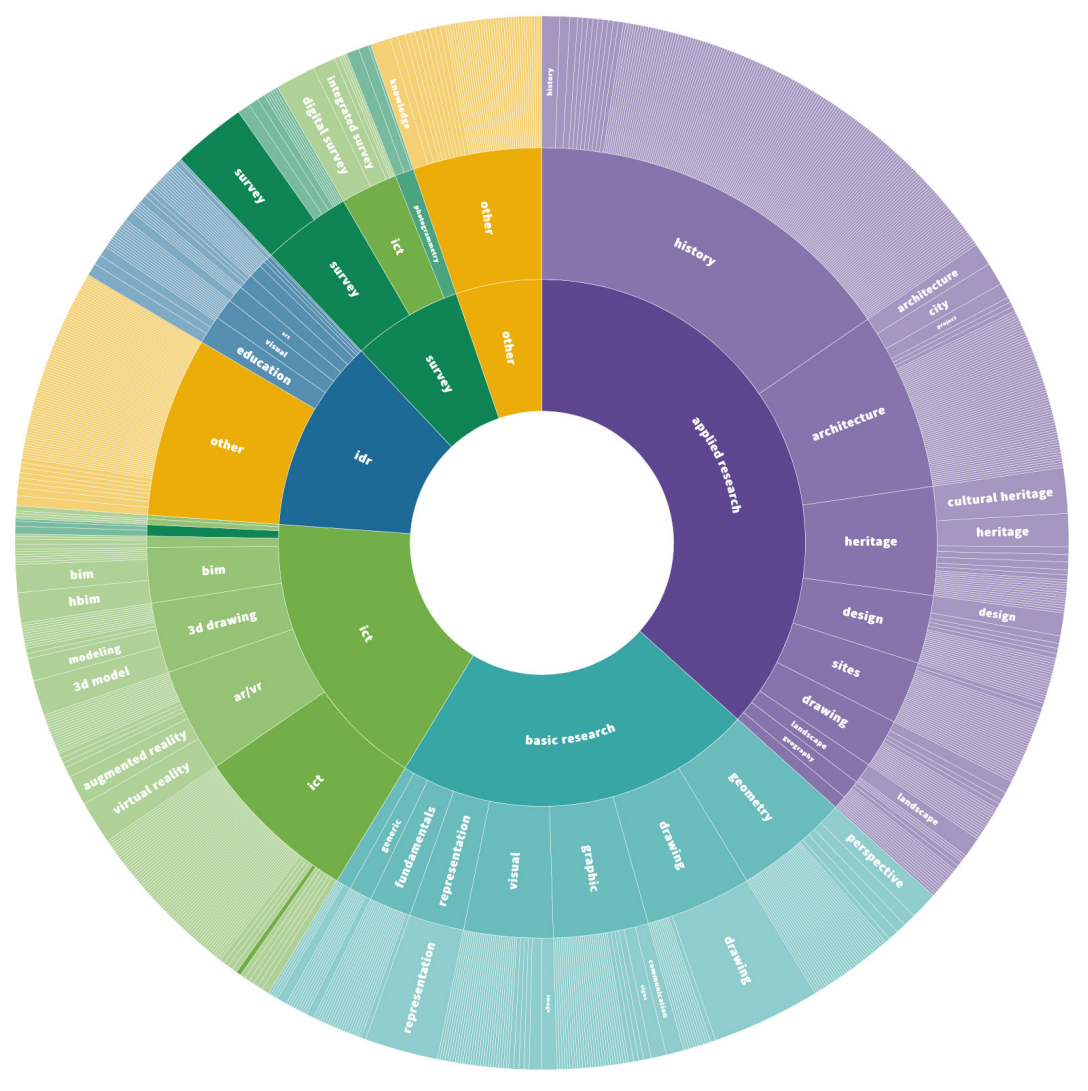


associate anche ad altri cluster (es: la keyword cultural heritage è stata inserita, per analogia al più generico termine heritage, nel macro-tema history, ma per la sua natura ampia avrebbe potuto essere annoverato tra i temi IDR) ma ai fini del nostro lavoro - di proposta metodologica e non esaustiva - abbiamo ritenuto che una distinzione del genere potesse restituire considerazioni sufficientemente significative.

Una volta definito, il dataset è stato visualizzato in modo da poter osservare l'incidenza di ogni area disciplinare, di ogni macro-tema e la frequenza delle singole keywords nei contributi presentati nei Convegni UID 2018 e 2019.

\section{Analisi dei dati}

La figura I mostra la distribuzione di quantità delle singole keywords, nella corona esterna, dove si possono notare che risultano leggibili solo alcune keywords, la cui frequenza è superiore a 5. Possiamo così verificare che le keywords che presentano una frequenza uguale o superiore a 6 sono:

Tenendo conto che alcune keywords hanno carattere più generale (le prime tre, ad esempio, Survey potrebbe essere riferita a decine di altri contributi mentre Representation con 29

\begin{tabular}{llll}
\hline Drawing & 43 & Integrated survey & 9 \\
\hline Survey & 29 & City & 9 \\
\hline Representation & 29 & Architecture & 9 \\
\hline Cultural Heritage & 18 & Design & 9 \\
\hline Virtual Reality & 17 & Modeling & 9 \\
\hline Digital survey & 16 & Knowledge & 8 \\
\hline 3D model & 14 & Landscape & 8 \\
\hline Heritage & 13 & Communication & 7 \\
\hline HBIM & 12 & History & 7 \\
\hline Augmented Reality & 12 & Project & 6 \\
\hline Perspective & 11 & Image & 6 \\
\hline BIM & 11 & Sign & 6 \\
\hline
\end{tabular}

ricorrenze e Drawing con 43, in sostanza potrebbero essere riferite alla quasi totalità dei paper presentati nei due convegni) e alcuni hanno carattere più specifico, c'è da osservare anche che molti sono declinazioni di uno stesso tema (ad esempio Survey, Digital survey e Integrated survey per un totale di 64 ricorrenze) pertanto questa osservazione ha un impatto complessivo circoscritto. Più interessante, forse, notare che HBIM (I2) ha superato seppur di poco per frequenza di BIM (I I), che la perspective tra tutti i modelli proiettivi e più in generale tra i temi della geometria descrittiva, resta sempre un punto di riferimento, e che tra le 24 keywords più frequenti troviamo anche communication (7) e image (6).

Nella corona centrale si trovano tutti i macro-temi e per poterli leggere in maniera più approfondita si è proceduto con la visualizzazione di ogni singolo macro-tema, come mostrato in figura 2.

Come si può facilmente vedere ci sono, tra le altre, due osservazioni da evidenziare: la prima è che molte keywords etichettate nella categoria other, come forse ci si poteva aspettare, rientrano nell'area di ricerca interdisciplinare (IDR), mentre la seconda è che al variare di piccoli dettagli alcune keyword riconducibili alla survey sono annoverati nell'ICT e alcune riconducibili alle ICT sono comprese nella survey: questo è un caso emblematico di come sia problematica la categorizzazione di keywords in base a macro temi, caso risolto con una osservazione di tipo linguistico che distingue l'uso dei termini riferibili a survey o ICT in base alla sintassi (3D survey è 'prima' ICT e 'poi' survey, mentre digital survey è 'prima' survey e 'poi' 

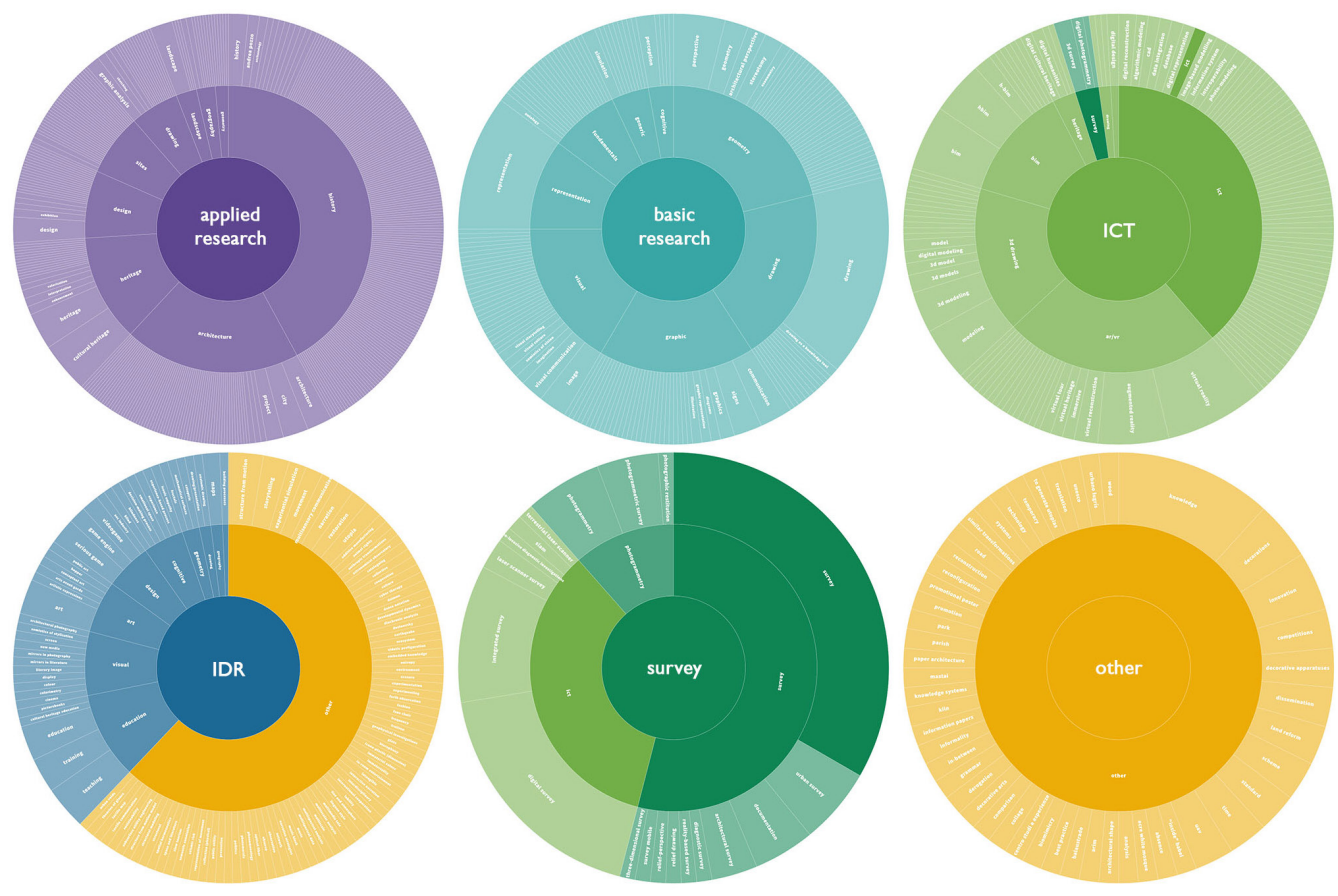

$I C T)$ e, in caso di ulteriori dubbi, con una valutazione speditiva del contenuto del paper. La figura 3 ci mostra in dettaglio la frequenza delle keywords riconducibili all'interdisciplinarità, per un parziale di 153 keywords su un totale di I 289, ossia l'I I,9\% del totale.

Allinterno di questa categoria possiamo osservare una incidenza maggioritaria - circa 2/3 - di keywords non direttamente identificabili con una area disciplinare, seppur appartenente ad altre discipline, mentre la restante parte vede come macro-temi ricorrenti: education (I5), visual (I I), art (9), design (8), cognitive (7), geometry (3), drawing (2), geography (2), architecture ( $\mathrm{I}$ ). Alcuni di questi macro-temi sono distribuiti anche in altre aree disciplinari, ma i dati che ci paiono osservabili sono:

I) il progressivo consolidarsi della ricerca in campo educativo - a ogni ordine e grado - che inizia a superare un pregiudizio ricorrente nei confronti della 'didattica', con una maggiore consapevolezza della distinzione tra 'documentazione didattica' - di modesto impatto scientifico - e 'ricerca in ambito didattico' - di notevole impatto scientifico -;

2) le keywords riconducibili al macro-tema 'visual' (comprendente i visual studies e bildwissenschaft, l'iconografia e l'iconologia, la semiotica visuale, gli screen studies, la comunicazione visiva, il visual thinking etc.) hanno una frequenza più alta nella ricerca di base (47) che nella ricerca interdisciplinare ( $\mathrm{I}$ I), il che porta a presumere che siano temi assimilati dalla comunità scientifica del Disegno;

3) le keywords di area psicologica-cognitiva non sono molto numerose (7), soprattutto a confronto alla frequenza delle ricerche sulla realtà virtuale e altre keywords contenenti il termine immersive (complessivamente 28) che, quindi, richiederebbero forse maggiore approfondimento interdisciplinare dal punto di vista cognitivo;

4) l'alto numero di keywords non associabili direttamente a un'area disciplinare suggeriscono l'ipotesi che ci sia una ampia offerta di temi interdisciplinari in via di sviluppo, al di là del consolidamento delle aree psico-pedagogiche e dei visual studies all'interno della disciplina. 


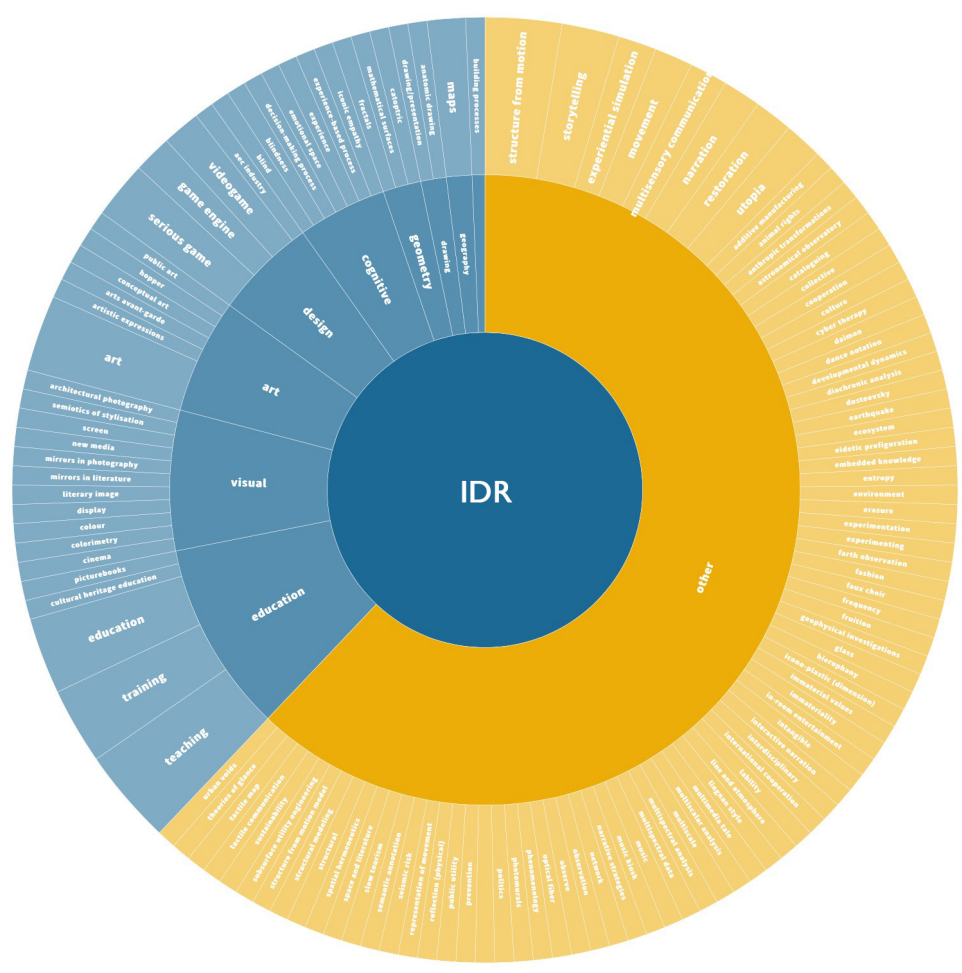

\section{Conclusioni}

La circoscritta lettura dello stato dell'arte per quanto concerne la valutazione della ricerca interdisciplinare, ci ha consentito di definire i termini multidisciplinarità, interdisciplinarità, transdisciplinarità, crossdisciplinarità e di porre alcune attenzioni nella impostazione metodologica della lettura del corpus delle keywords dei contributi degli ultimi due convegni UID tenutisi nel 2018 e nel 2019. In primis la necessità di uniformare e di organizzare in macro-temi e cluster le keywords, che seppur passibile di un contenuto grado di arbitrarietà e un buon margine di raffinamento, ha consentito la aggregazione dei dati e una lettura complessiva.

Una ulteriore considerazione è utile per stimare quanto i due paradigmi della ricerca interdisciplinare - interdisciplinarità come 'integrazione di sapere' [National Academies 2004; Porter et al. 2006] o come 'intermediazione' [Leydesdorff 2007a] - incidano nella definizione dell'appartenenza delle keywords al cluster IDR. Due esempi saranno utili per chiarire questa considerazione.

La keyword blindness è stata inserita nel cluster IDR perché presenta un tema tipico delle scienze cognitive e la ricerca in cui questa keyword è inserita presenta necessariamente una integrazione di sapere, perché il campo della 'visione' si pone da ponte tra le discipline e costituisce, appunto, una integrazione tra esse. La keywords restoration, sicuramente più vicina allo specifico del nostro settore, è stata considerata IDR perchè trattasi di una disciplina con cui la nostra area può avere un rapporto integrato o strumentale.

Questa ultima considerazione ne favorisce un'altra. Se è vero che la ricerca interdisciplinare è un insieme eterogeneo di metodi, strumenti e teorie disciplinari, è importante sottolineare che questi insiemi trovano il loro equilibrio con dinamiche differenti se le discipline che partecipano alla ricerca sono 'limitrofe' o 'distanti': nel caso di discipline 'limitrofe' (es: disegno/ composizione architettonica o disegno/restauro) uno degli aspetti da valutare è la possibile sovrapposizione delle competenze coinvolte, che può favorire la comunicazione ma anche l'insorgenza di punti di vista differenti su questioni comuni, mentre nel caso di discipline 'distanti' (es: disegno e psicologia cognitiva o disegno e sociologia) è necessaria una maggiore componente di 'integrazione di sapere' rispetto alla 'intermediazione'. In questo caso si parla 
Fig. 5. Distribuzione dei macro-temi con indicazione quantitativa della frequenza.

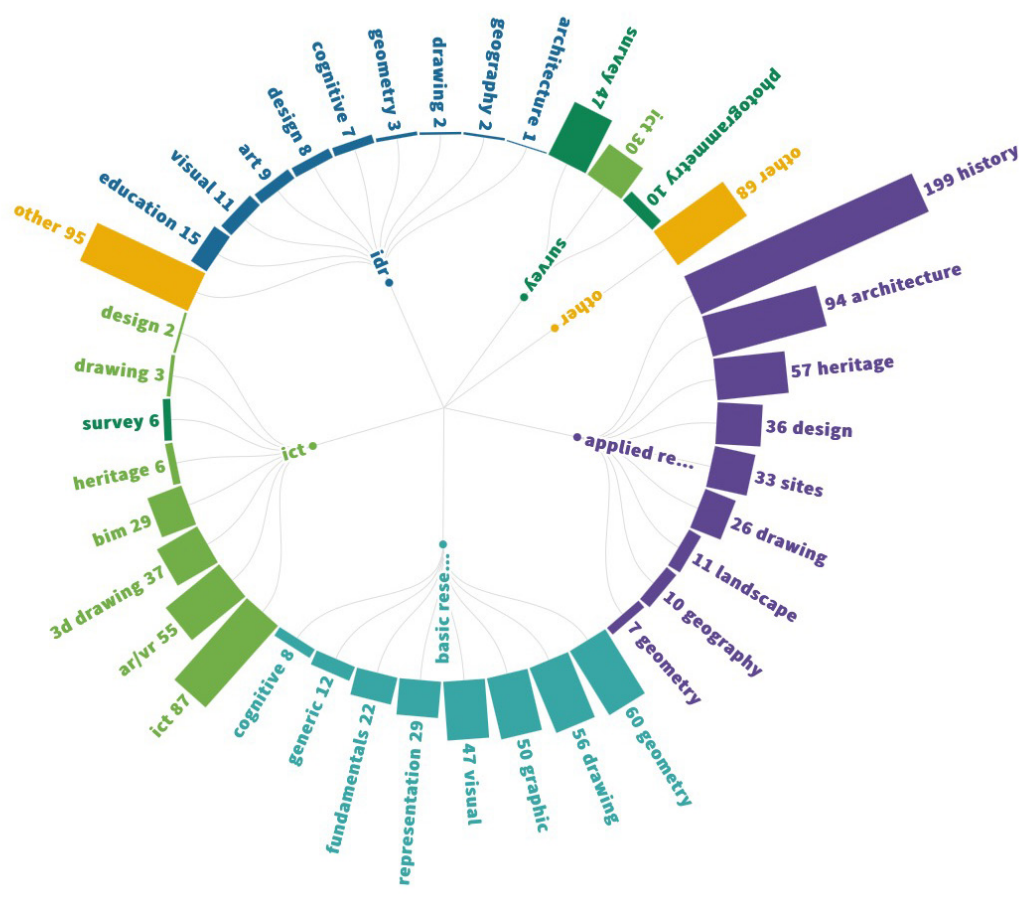

di alta 'disparità', ovvero di una distanza (misurabile con modelli statistici) tra i temi trattati dalle discipline, utile alla messa in relazione tra domini disciplinari che concorrono alla ricerca interdisciplinare.

In definitiva lo studio si propone come un punto di partenza per un processo ampio e condiviso di valutazione delle modalità in cui sviluppare e valutare la ricerca interdisciplinare. Possibili sviluppi possono essere concentrati prima di tutto su un ampliamento del campione estendendo l'osservazione almeno dal 2015 al 2020, che oltre ad aumentare l'attendibilità delle osservazioni di ordine quantitativo consentirebbe di valutare i trend di sviluppo dei vari macro-temi e dei cluster di anno in anno. Inoltre, dal punto di vista metodologico l'ampliamento del dataset ad altre informazioni deducibili dai contributi (affiliazione autori, singolo autore o più autori, correlazione di keywords appartenenti a un singolo contributo, etc.) potrebbe consentire ulteriori e più approfondite analisi sullo stato dell'arte della ricerca interdisciplinare nel settore scientifico disciplinare del Disegno.

\section{Note}

[I] Disponibile alla pagina https://www.youtube.com/watch?v=xMCn56AAVj0.

\section{Riferimenti bibliografici}

Barry Andrew, Born Georgina, Weszkalnys Gisa (2008). Logics of interdisciplinarity. In Economy and Society 37 (I), pp. 20-49.

Belardi Paolo (ed.) (2019). Reflections: the art of drawing/the drawing of art. Proceedings of the 4Ith International Conference of Teachers of the disciplines of the Representation. Perugia 19-21 Septembre 20 19. Roma: Gangemi Editore.

Bromham Lindell, Dinnage Russel, Hua Xia (2016). Interdisciplinary research has consistently lower funding success. In Nature, Jun 30; 534(7609): pp. 684-6877. doi: I0.1038/nature I8315.

Bruce Ann, et al. (2004). Interdisciplinary integration in Europe: the case of the Fifth Framework programme. In Futures, 36 , pp. $457-470$.

Davé Anoushka et al. (20 I 6). Landscape Review of Interdisciplinary Research in the UK. Report to HEFCE and RCUK by Technopolis and the Science Policy Research Unit (SPRU). Sussex: University of Sussex.

Gibbons Michael et al. (1994). The New Production of Knowledge:The Dynamics of Science and Research in Contemporary Societies. London: Sage Publications.

Heinze Thomas et al. (2009). Organizational and institutional influences on creativity in scientific research. In Research Policy, 38, pp. $610-623$. 
Hemlin Sven, Allwood C. Martin R. Ben (eds.). (2004). Creative Knowledge Environments: the Influences on Creativity in Research and Innovation. Cheltenham (UK): Edward Elgar.

Jacobs Jerry A., Frickel Scott (2009). Interdisciplinarity: a critical assessment. In Annual Review of Sociology, 35, pp. 43-65.

Klein T. Julie (2008). Evaluation of Interdisciplinary and Transdisciplinary Research. A Literature Review. In American Journal of Preventive Medicine, 35(2), pp. I I6- 123

Langfeldt Liv (2006). The policy challenges of peer review: managing bias, conflict of interests and interdisciplinary assessments. In Research Evaluation, I5 (I), pp. 31-4I.

Laudel Grit, Origgi Gloria (2006). Introduction to a special issue on the assessment of interdisciplinary research. In Research Evaluation, 15 ( I), pp. 2-4.

Leydesdorff Loet (2007). Betweenness centrality as an indicator of the interdisciplinarity of scientific journals. In Journal of the American Society for Information Science and Technology, 58 (9), pp. I303-1319.

Martin R. Ben, Irvine John (1983). Assessing basic research. Some partial indicators of scientific progress in radio astronomy. In Research Policy, 12, pp. $61-90$.

National Academies (2004). Facilitating Interdisciplinary Research. Committee on Science, Engineering, and Public Policy (Cosepup) Committee on Facilitating Interdisciplinary Research. Washington DC: National Academies Press.

Nightingale Paul, Scott Alister (2007). Peer review and the relevance gap: ten suggestions for policy-makers. In Science and Public Policy, 34 (8), pp. 543-553.

Page E. Scott (2007). The Difference. How the Power of Diversity Creates Better Groups, Firms, Schools, and Societies. Princenton (NJ): Princeton University Press.

Porter L. Alan et al. (2006). Interdiscipinary research: meaning, metrics and nurture. In Research Evaluation, I 5, pp. I87- I96.

Price D. J. De Solla (1984). The science/technology relationship, the craft of experimental science, and policy for the improvement of high technology innovation. In Research Policy, I3, pp. 3-20.

Rafols Ismael et al. (2012). How journal rankings can suppress interdisciplinary research: a comparison between innovation studies and business \& management. In Research Policy, 4I, pp. I262- 282.

Rinia J. Ed et al. (200 Ia). Influence of interdisciplinarity on peer-review and bibliometric evaluations in physics research. In Research Policy, 30 (3), pp. 357-361.

Rinia J. Ed, Van Leeuwen N. Thed, Van Raan F. J. Anthony (200 Ib). Impact measures of interdisciplinary research in physics. In Scientometrics, 53 (2), pp. 24I-248.

Rossini A. Frederick, Porter L. Alan (1979). Frameworks for integrating interdisciplinary research. In Research Policy, 8, pp. 70-79.

Salerno Rossella (ed.) (2018). Drawing as (in)tangible representation. Proceedings of the 40th International Conference of Teachers of the disciplines of the Representation. Milan 13- I5 September. Roma: Gangemi Editore.

Stirling Andy (20 I0). Keep it complex. In Nature, 468, pp. I029-I031.

Wagner S. Caroline et al. (20I I). Approaches to understanding and measuring interdisciplinary scientific research (IDR): a review of the literature. In Journal of Informetrics, 5 ( I), pp. I4-26.

\section{Autore}

Alessandro Luigini, Libera Università di Bolzano, alessandro.luigini@unibz.it

Per citare questo capitolo: Luigini Alessandro (2020). Ricerca interdisciplinare e ICARI 7: una proposta per la definizione di un modello condiviso/ Interdisciplinary research and ICAR I 7: a proposal for the definition of a shared model. In Arena A., Arena M., Brandolino R. G., Colistra D., Ginex
G., Mediati D., Nucifora S., Raffa P. (a cura di). Connettere. Un disegno per annodare e tessere. Atti del $42^{\circ}$ Convegno Internazionale dei Docenti delle G., Mediati D., Nucifora S., Raffa P. (a cura di). Connettere. Un disegno per annodare e tessere. Atti del $42^{\circ}$ Convegno Internazionale dei Docenti delle
Discipline della Rappresentazione/Connecting. Drawing for weaving relationships. Proceedings of the 42 th International Conference of Representation

Discipline della Rappresentazione/Connecting. Drawing for
Disciplines Teachers. Milano: FrancoAngeli, pp. 567-584. 


\section{Interdisciplinary Research and ICAR I7: a Proposal for the Definition of a Shared Model}

Alessandro Luigini

\section{Abstract}

The aim of this paper is to present the results of some international studies that have investigated the evaluation of interdisciplinary research, and then to present general observations on the discipline of Drawing, as defined by the corpus of scientific production of scholars in this area, taking as a sample the publications of two International Conferences of Representation Disciplines Teachers held in Milan in 2018 and Perugia in 2019. In addition, a possible research model -of a statistical nature- for interdisciplinary trends in the disciplinary field will be proposed, starting from general evaluations deduced from the observation of the keywords of the contributions to the UID conferences in 2018 and 2019.

\section{Keywords}

interdisciplinarity, drawing, heteronomy, disciplinary disparity.

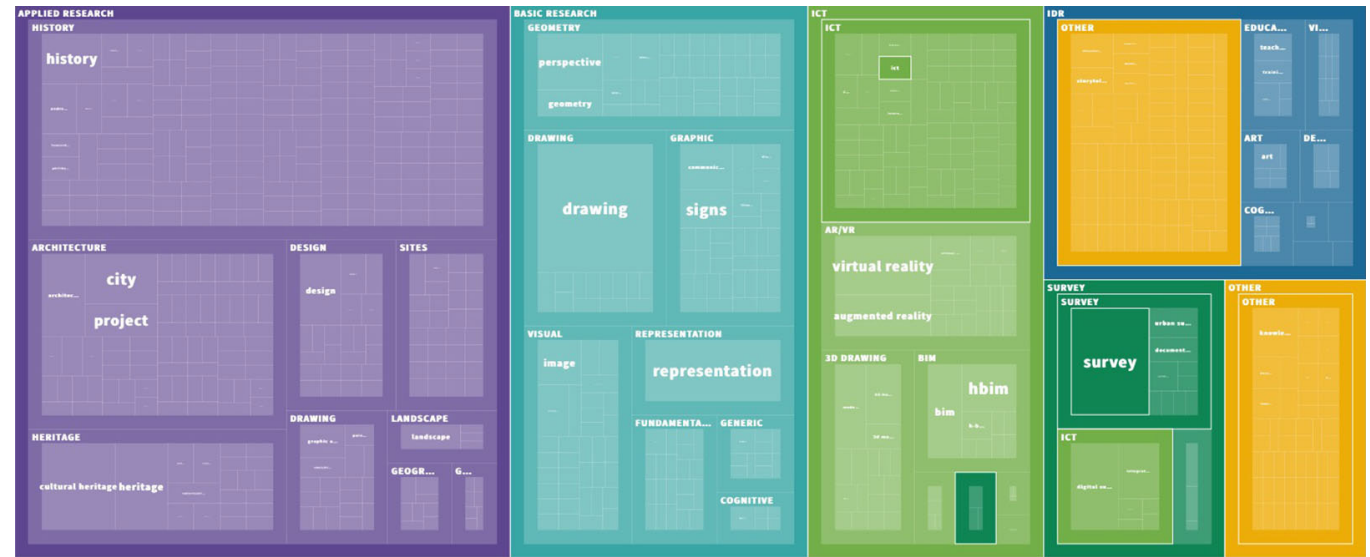




\section{Introduction}

Dealing with the theme of interdisciplinary research is always stimulating because it is probably more appropriate to the contemporary paradigm of the progress of knowledge, and because it allows us to look beyond disciplinary boundaries, keeping our feet firmly within the known and solid space of the discipline, but interpreting disciplinary boundaries as a reference boundary and not as a limit.

As is clear to many people, the scientific disciplinary field ICAR I7 Design is a heterogeneous sector, partly heteronomous, which has developed thanks to the confluence of knowledge derived from Hard Science and Humanities, as was mentioned in the 2nd Seminar on the evaluation of research held at the Department of History, Design and Restoration of Architecture of Sapienza University of Rome last March 4 [I]. This heterogeneity, as in many other cases, is an opportunity but also a source of risk.

The present contribution aims to deepen -briefly, for reasons of space- the topic of interdisciplinary research by making reflections on terminology, methodology, domain and observation of the state of the art, and then propose a possible methodology for evaluating the impact of interdisciplinary research in our disciplinary scientific field.

\section{Definitions}

The usual needs for clarity in scientific writing, require us to start from the definition of what is meant by 'interdisciplinarity' and other similar models that are occasionally used licentiously- as synonyms.

Since we are dealing with terminological determination in the scientific field, we have chosen to use both the linguistic definition.

The terms that define research that differs from disciplinary research are: pluri- or 'multidisciplinary', 'interdisciplinary' and 'transdisciplinary'.

a) Pluri- or multidisciplinary. In the field of research, it speaks of activities pluri- or multisiciplinary in which "theories, methods and interpretative standards of the different disciplines are used. The interpretation of the results of the different disciplines is typically post hoc, often from the point of view of a discipline that may emerge as dominant within the project" [Rossini, Porter 1979]. In this context, therefore, the disciplines contribute together to the development of the project, each with its own specific methodological and epistemological framework, with a hierarchy between dominant and participating disciplines.

b) Interdisciplinary. In the scientific literature, interdisciplinary research is defined as research in which "approaches integrate separate data, methods, tools, concepts and disciplinary theories to create a holistic view or common understanding of a complex issue, question or problem" [Wagner et al. 20 I I, p. I6].

The holistic view recalled in this definition reminds us that complexity cannot be governed by simple models and, without indulging in uncontrolled experimentation with unconventional models, it is necessary to formulate complex -or multiple- answers to answer equally complex questions.

c) Transdisciplinary. In the literature it is defined as transdisciplinary "cross-sectoral, problem-oriented research involving a wider range of stakeholders in society" [Klein 2008, p. I I7]. This definition opens up further questions to be debated, which here, for the sake of brevity, we limit ourselves to emphasizing: transdisciplinary research not only tends to go beyond the boundaries of disciplines, but is addressed to a wide range of stakeholders and, therefore, to a multiplicity of instances to be taken into account.

d) Cross disciplinary. The term cross-disciplinary, more simply "is often used to describe the three research modalities defined above" [Davè et al. 2016, p. 13]. 


\section{State of the art}

In the last decades the frequency of the interdisciplinary term and others related to it that we discussed in the previous paragraph has been increasing with a positive trend. Many studies show that interdisciplinarity is often indicated as one of the factors that contribute to the promotion of innovation [Gibbons et al. 1994] and creativity [lacobs, Frickel 2009] also because it is more effective in the search for solutions to complex problems [Page 2007, p. 16], because it is able to question established beliefs [Barry et al. 2008] and to foster creativity [Heinze et al. 2009; Hemlin et al. 2004]. But despite these premises, other studies show that interdisciplinary research is perceived as a disadvantage when entering the evaluation process [Rinia et al. 200 I a, p. 357; Nightingale, Scott 2007, pp. 546, 547] and in some cases it has been shown, on a qualitative basis, that peer review is often negatively influenced by interdisciplinarity [Laudel, Origgi 2006; Langfeldt 2006, p. 3I].

A stimulating study, from which we have taken many cues and a good part of the readings made to write these pages, analyses on a quantitative basis the disincentive mechanisms of interdisciplinary research in some contexts of economic research in Great Britain [Rafols et. al. 20 12]. The authors demonstrate for the first time the bias against interdisciplinary research on a quantitative basis and that such bias can be observed not only in peer review but also in evaluations considered less subject to the variability of a reviewer's judgement, as in the case of journal classifications or in the case of research evaluation systems, in Great Britain called REF - Research Excellence Framework, similarly to ANVUR's classification of scientific journals and class A journals and ourVQR - Evaluation of Research Quality.

In this perspective, the authors examine the three main areas of evaluation that revolve around scientific publications: journal classification, peer review and evaluation of research quality.

The first criticism made by Rafols and the other authors is the narrow selection of indicators used for the evaluation, in some cases a single bibliometric indicator, the citation indicator. According to several other studies [Martin, Irvine 1983; Stirling 20 I0] the use of a number of partial indicators is more appropriate for the evaluation of multidimensional concepts such as interdisciplinarity [Rafols et al. 2012, p. 1263].

This framework, however, which is adverse to the development of interdisciplinary research, is criticized by some methodological observations: interdisciplinary research is often referred to as "risk oriented", based on unclear grounds from a disciplinary point of view [Bruce et al. 2004] and occasionally there is the risk that interdisciplinarity is only one of the factors that make research relevant, and not necessarily one of the most determinant [Rafols et al. 2012, p. 1264].

All these critical issues have the effect of slowing down the development of interdisciplinary networks, also due to the poor career prospects for researchers inclined to interdisciplinary research and the further difficulty to publish in prestigious journals [Bruce et al. 2004, p. 464]. It has also been shown that interdisciplinary research has more space in journals with les citation impact than strictly disciplinary research [Rinia et al. 200 I a, p. 360; Rinia et al. 200 I b, p. 247] and that interdisciplinary research is less likely to be funded by national research funding programmes [Bromham et al. 20I6].

\section{Methodology}

The narrow review of the scientific literature on the evaluation of interdisciplinary research, provides us with a ground on which to set up an observation, mainly of a qualitative nature but on a quantitative basis, of the state of the art with regard to interdisciplinary research in our disciplinary scientific field, useful -in an in-depth study following this writing- to provide shared references for the evaluation of interdisciplinary research. Far from being exhaustive, this study provides the groundwork for a shared discussion by focusing on some metadata for indexing, i.e. the 'keywords'. 
The proceedings of the last two International Conferences of Representation Disciplines Teachers, held in Milan in 2018 and in Perugia in 2019, were examined. The themes of the conferences were: Representation/Material//mmaterial. Drawing as (in)tangible representation [Salerno 20 I8] for the conference held in Milan in 2018, and Reflections, the art of drawing I the drawing of art [Belardi 2019] for the conference held in Perugia in 2019. The contributions examined are those in English language.

The keywords of all contributions have been included in a dataset for quantitative processing, for a total of 1289 elements that outline a wide range of interests developed in our disciplinary field. The keywords have been subsequently uniform and aggregated: uniform, because the data were not sufficiently 'sharp' from the beginning, presenting numerous declinations of particularly widespread themes (e.g. 3D modeling, 3D models, 3D modeling), which would have necessarily altered the analyses, and aggregated because the great variability of the keywords, even after the standardisation, would not have allowed a significant reading of the frequency of disciplinary areas and themes.

This process, central in the setting up of this work, requires further methodological in-depth analysis, in addition to an expansion of the sample as a future outlook.

\section{Aggregation in clusters}

The data set was organized on three levels: the most external (fig. I) is the level that contains all the standardised keywords; the intermediate level indicates the macro-theme to which each single keyword is referred (architecture, design, landscape, geography, site, history, heritage, survey, ICT, BIM, drawing, geometry, graphic, visual, cognitive, basis, generic, education, other); the inner level indicates some clusters (basic research, applied research, survey, ICT, IDR, other), which are assigned to the single keyword and not to the macro-themes. This last clarification suggests that two keywords within the same macro-theme can be assigned to two different clusters (e.g.: the keyword 'visual culture' is part of the 'visual' macro-theme

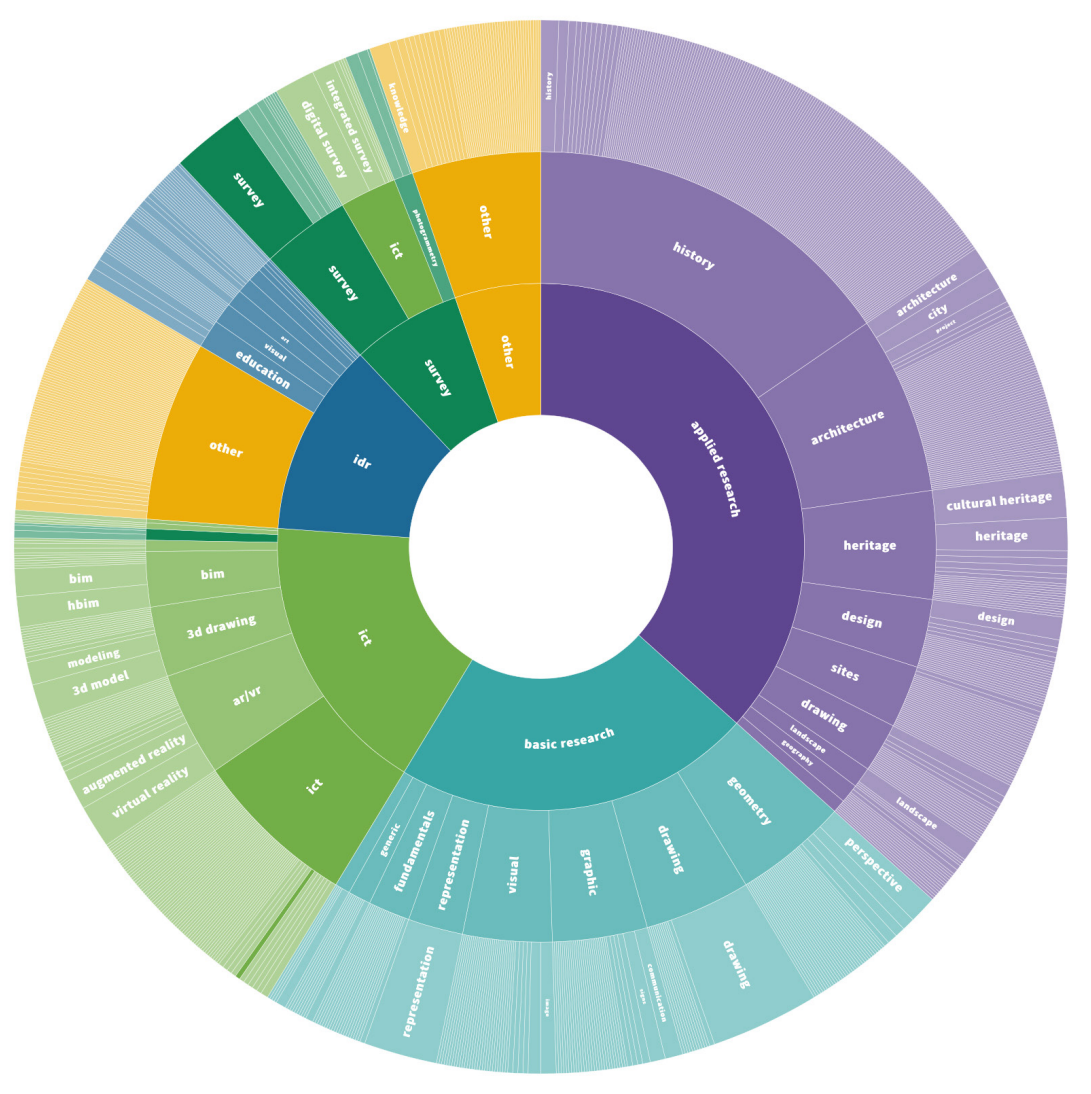


and the ]basic research' cluster, the keyword 'screen' is always part of the 'visual' macro-theme but of the IDR cluster).

We immediately point out that this whole is not completely homogeneous, since many cases -if not almost all- of keywords related to applied research can also be associated to other clusters (e.g.: the keyword 'cultural heritage' has been included, by analogy to the more generic term heritage, in the macro-theme 'history', but due to its wide nature it could have been included among the IDR themes) but for the purposes of our work - of methodological proposal and not exhaustive - we thought that such a distinction could give back sufficiently significant considerations.

Once defined, the dataset was displayed in order to observe the incidence of each disciplinary area, each macro-theme and the frequency of the single keywords in the contributions presented at the 2018 and 2019 UID Conferences.

\section{Data analysis}

Figure I shows the quantity distribution of the single keywords, in the external crown, where you can see that only some keywords, whose frequency is higher than 5 , are readable. We can thus verify that the keywords with a frequency equal to or greater than 6 are:

\begin{tabular}{llll}
\hline Drawing & 43 & Integrated survey & 9 \\
\hline Survey & 29 & City & 9 \\
\hline Representation & 29 & Architecture & 9 \\
\hline Cultural Heritage & 18 & Design & 9 \\
\hline Virtual Reality & 17 & Modeling & 9 \\
\hline Digital survey & 16 & Knowledge & 8 \\
\hline 3D model & 14 & Landscape & 8 \\
\hline Heritage & 13 & Communication & 7 \\
\hline HBIM & 12 & History & 7 \\
\hline Augmented Reality & 12 & Project & 6 \\
\hline Perspective & 11 & Image & 6 \\
\hline BIM & 11 & Sign & 6 \\
\hline
\end{tabular}

Considering that some keywords have a more general character (the first three, for example, 'Survey' could be referred to dozens of other contributions while 'Representation' with 29 recurrences and 'Drawing' with 43, in essence could be referred to almost all the papers presented at the two conferences) and some have a more specific character, it should also be noted that many are declensions of the same theme (e.g. Survey, Digital survey and Integrated survey for a total of 64 recurrences) so this observation has a narrow overall impact. More interesting, perhaps, to note that HBIM (12) has exceeded the frequency of BIM (I I), that the perspective among all projective models and more generally among the themes of descriptive geometry, remains always a reference point, and that among the 24 most frequent keywords we also find 'communication' (7) and 'image' (6).

In the central crown there are all the macro-themes and in order to read them in more depth we proceeded with the visualization of each macro-theme, as shown in figure 2 .

As you can easily see there are, among the others, two observations to highlight: the first is that many keywords labelled in the other category, as you might have expected, fall within the Interdisciplinary Research Area (IDR), while the second is that when small details vary, some keywords related to the 'survey' are included in the ICT and some related to ICT are included in the 'survey': This is an emblematic case of how problematic is the categorization of keywords based on macro themes, a case solved with a linguistic observation that distin- 

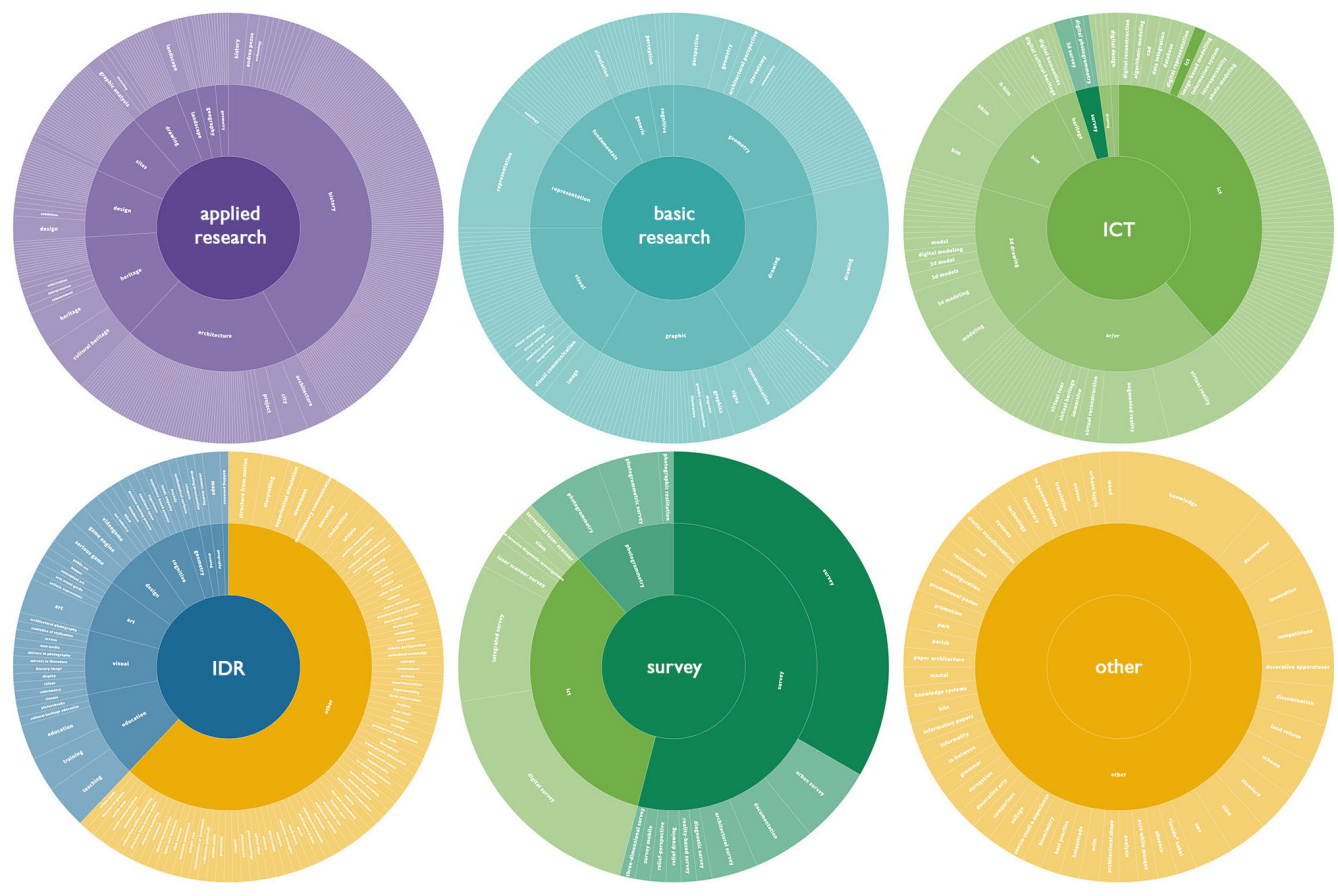

guishes the use of survey or ICT terms based on syntax (3D survey is 'first' ICT and 'then' survey, while digital survey is 'first' 'survey' and 'then' ICT) and, in case of further doubt, with a timely evaluation of the content of the paper.

Figure 3 shows us in detail the frequency of keywords attributable to interdisciplinarity, for a partial of 153 keywords out of a total of 1289, or I I.9\% of the total.

Within this category we can observe a majority incidence - about 2/3 - of keywords not directly identifiable with a disciplinary area, even if belonging to other disciplines, while the remaining part sees as recurrent macro-themes: education (I5), visual (I I), art (9), design (8), cognitive (7), geometry (3), drawing (2), geography (2), architecture (I). Some of these macro-themes are also distributed in other disciplinary areas, but the data that seem observable to us are:

I) the progressive establishment of research in the educational field - at all levels - which is beginning to overcome a common prejudice against 'didactics', with a greater awareness of the distinction between 'didactic documentation' - having a slight scientific impact - and 'research in the educational field' - having a remarkable scientific impact;

2) the keywords referable to the visual macro-theme (including visual studies and bildwissenschaft, iconography and iconology, visual semiotics, screen studies, visual communication, visual thinking, etc.) have a higher frequency in basic research (47) than in interdisciplinary research ( $\mathrm{II}$ ), which leads to the assumption that they are themes assimilated by the scientific community of Drawing;

3) the keywords of the psychological-cognitive area are very few (7), especially when compared to the frequency of research on virtual reality and other keywords containing the term 'immersive' (a total of 28) which, therefore, would perhaps require more interdisciplinary research from the cognitive point of view;

4) the high number of keywords that cannot be directly associated to a disciplinary area suggest the hypothesis that there is a wide range of interdisciplinary themes in development, beyond the consolidation of psycho-pedagogical areas and visual studies within the discipline. 
Fig. 4. Distribution of interdisciplinary macro-themes and keywords.

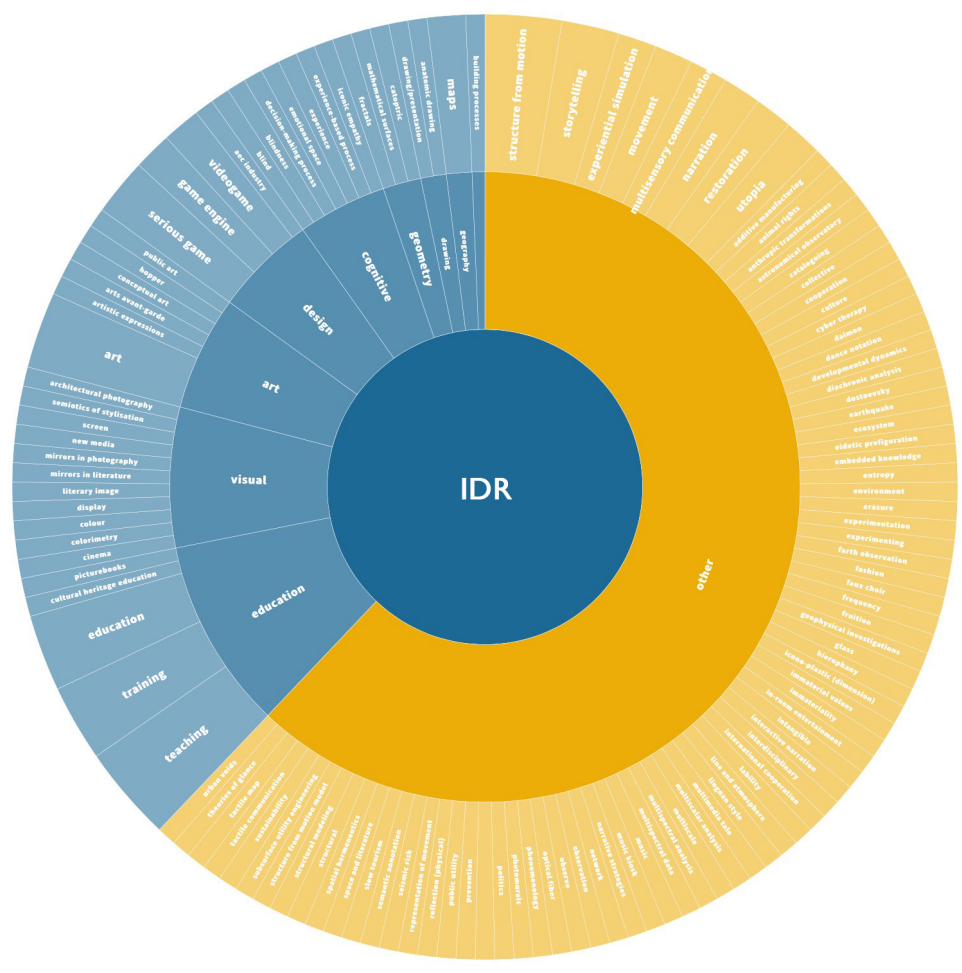

\section{Conclusions}

The circumscribed reading of the state of the art for the evaluation of interdisciplinary research has allowed us to define the terms multidisciplinarity, interdisciplinarity, transdisciplinarity, crossdisciplinarity and to put some attention in the methodological approach of the reading of the corpus of keywords of the contributions of the last two UID conferences held in 2018 and 2019. First of all, the need to standardize and organize the keywords into macro-themes and clusters, which, although subject to a degree of arbitrariness and a good margin of refinement, has allowed the aggregation of data and an overall reading.

A further consideration is useful to estimate how much the two paradigms of interdisciplinary research -interdisciplinarity as 'integration of knowledge' [National Academies 2004; Porter et al. 2006] or as 'intermediation' [Leydesdorff 2007a]- affect the definition of keywords belonging to the IDR cluster. Two examples will be useful to clarify this consideration.

The keyword 'blindness' has been included in the IDR cluster because it presents a theme typical of cognitive sciences and the research in which this keyword is included necessarily presents an integration of knowledge, because the field of 'vision' acts as a bridge between disciplines and constitutes an integration between them. The keyword 'restoration', certainly closer to the specifics of our sector, has been considered IDR because it is a discipline with which our area can have an integrated or instrumental relationship.

This last consideration supports another. If it is true that interdisciplinary research is a heterogeneous set of methods, tools and disciplinary theories, it is important to underline that these sets find their balance with different dynamics if the disciplines participating in the research are 'neighbouring' or 'distant': in the case of 'neighbouring' disciplines (e.g.,' research in the field of research'), it is important to underline that these sets find their balance with different dynamics if the disciplines participating in the research are 'neighbouring' or 'distant': design and architectural composition or design and restoration) one of the aspects to be evaluated is the possible overlapping of the skills involved, which may favour communication but also the emergence of different points of view on common issues, while in the case of 'distant' disciplines (e.g.: design and cognitive psychology or design and sociology) a greater 
Fig. 5. Distribution of macro-themes with quantitative indication of frequency.

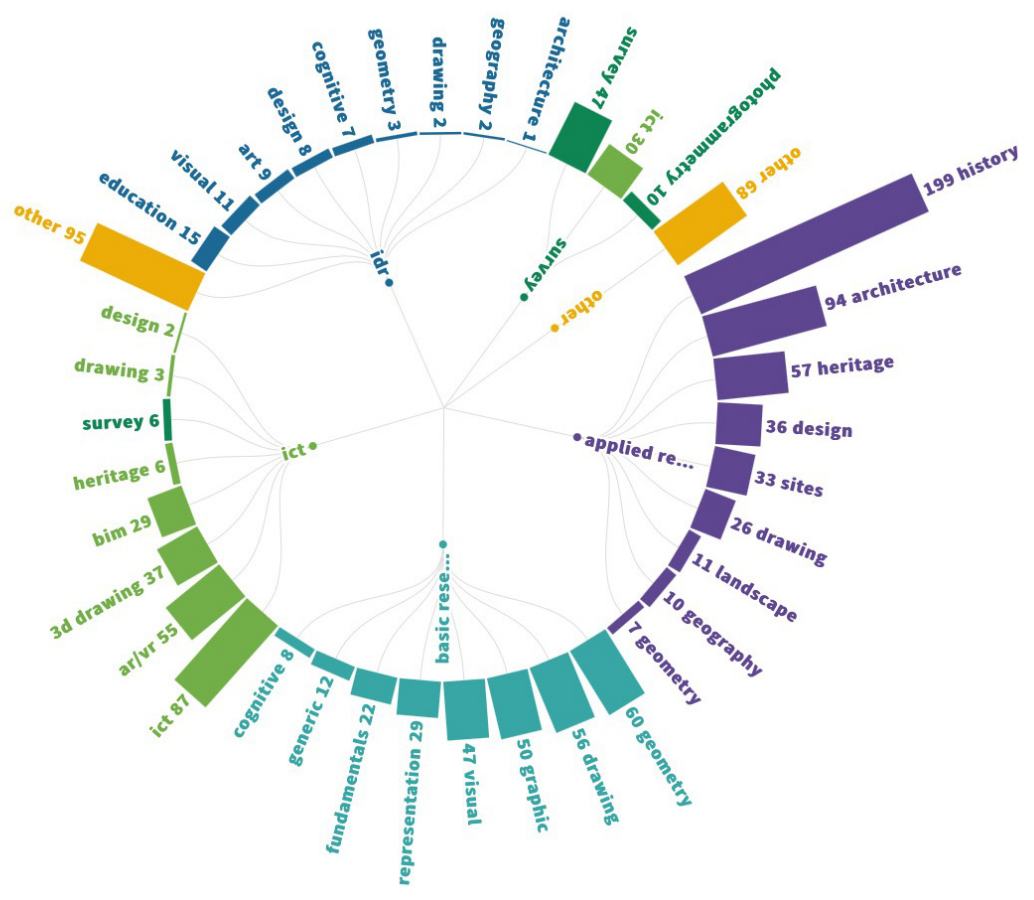

component of knowledge integration is needed than intermediation. In this case we speak of high 'disparity', i.e. a distance (measurable with statistical models) between the themes dealt with by the disciplines, useful to relate disciplinary domains that contribute to interdisciplinary research.

Ultimately, the study is proposed as a starting point for a broad and shared process of evaluation of how to develop and evaluate interdisciplinary research. Possible developments can be focused first of all on an expansion of the sample by extending the observation from at least 2015 to 2020, which, in addition to increasing the reliability of quantitative observations, would make it possible to assess the development trends of the various macro-themes and clusters from year to year. Moreover, from the methodological point of view, the extension of the dataset to other information deductible from the contributions (affiliation of authors, single author or more authors, correlation of keywords belonging to a single contribution, etc.) could allow further and more in-depth analysis on the state of the art of interdisciplinary research in the disciplinary scientific field of Design.

\section{Notes}

[I] Available on the web page: https://www.youtube.com/watch? $=x M C n 56 A A V j 0$

\section{References}

Barry Andrew, Born Georgina, Weszkalnys Gisa (2008). Logics of interdisciplinarity. In Economy and Society 37 ( I), pp. $20-49$.

Belardi Paolo (ed.) (2019). Reflections: the art of drawing/the drawing of art. Proceedings of the 4 I th International Conference of Teachers of the disciplines of the Representation. Perugia 19-2I Septembre 2019. Roma: Gangemi Editore.

Bromham Lindell, Dinnage Russel, Hua Xia (2016). Interdisciplinary research has consistently lower funding success. In Nature, Jun 30; 534(7609): pp. 684-6877. doi: 10.1038/nature I8315.

Bruce Ann, et al. (2004). Interdisciplinary integration in Europe: the case of the Fifth Framework programme. In Futures, 36 , pp. 457-470.

Davé Anoushka et al. (2016). Landscape Review of Interdisciplinary Research in the UK. Report to HEFCE and RCUK by Technopolis and the Science Policy Research Unit (SPRU). Sussex: University of Sussex.

Gibbons Michael et al. (1994). The New Production of Knowledge:The Dynamics of Science and Research in Contemporary Societies. London: Sage Publications. 
Heinze Thomas et al. (2009). Organizational and institutional influences on creativity in scientific research. In Research Policy, 38, pp. $610-623$

Hemlin Sven, Allwood C. Martin R. Ben (eds.). (2004). Creative Knowledge Environments: the Influences on Creativity in Research and Innovation. Cheltenham (UK): Edward Elgar.

Jacobs Jerry A., Frickel Scott (2009). Interdisciplinarity: a critical assessment. In Annual Review of Sociology, 35, pp. 43-65.

Klein T. Julie (2008). Evaluation of Interdisciplinary and Transdisciplinary Research. A Literature Review. In American Journal of Preventive Medicine, 35(2), pp. I | 6- 123.

Langfeldt Liv (2006). The policy challenges of peer review: managing bias, conflict of interests and interdisciplinary assessments. In Research Evaluation, I5 (1), pp. 31-4I.

Laudel Grit, Origgi Gloria (2006). Introduction to a special issue on the assessment of interdisciplinary research. In Research Evaluation, 15 ( I), pp. 2-4.

Leydesdorff Loet (2007). Betweenness centrality as an indicator of the interdisciplinarity of scientific journals. In Journal of the American Society for Information Science and Technology, 58 (9), pp. I303- 1319.

Martin R. Ben, Irvine John (1983). Assessing basic research. Some partial indicators of scientific progress in radio astronomy. In Research Policy, I2, pp. 61-90.

National Academies (2004). Facilitating Interdisciplinary Research. Committee on Science, Engineering, and Public Policy (Cosepup) Committee on Facilitating Interdisciplinary Research. Washington DC: National Academies Press.

Nightingale Paul, Scott Alister (2007). Peer review and the relevance gap: ten suggestions for policy-makers. In Science and Public Policy, 34 (8), pp. 543-553.

Page E. Scott (2007). The Difference. How the Power of Diversity Creates Better Groups, Firms, Schools, and Societies. Princenton (NJ): Princeton University Press.

Porter L. Alan et al. (2006). Interdiscipinary research: meaning, metrics and nurture. In Research Evaluation, I5, pp. I87- 196.

Price D. J. De Solla (1984). The science/technology relationship, the craft of experimental science, and policy for the improvement of high technology innovation. In Research Policy, I3, pp. 3-20.

Rafols Ismael et al. (2012). How journal rankings can suppress interdisciplinary research: a comparison between innovation studies and business \& management. In Research Policy, 41, pp. I262- 1282.

Rinia J. Ed et al. (200 la). Influence of interdisciplinarity on peer-review and bibliometric evaluations in physics research. In Research Policy, 30 (3), pp. 357-36I.

Rinia J. Ed, Van Leeuwen N. Thed, Van Raan F. J. Anthony (200 Ib). Impact measures of interdisciplinary research in physics. In Scientometrics, 53 (2), pp. 24I-248.

Rossini A. Frederick, Porter L. Alan (1979). Frameworks for integrating interdisciplinary research. In Research Policy, 8, pp. 70-79.

Salerno Rossella (ed.) (2018). Drawing as (in)tangible representation. Proceedings of the 40th International Conference of Teachers of the disciplines of the Representation. Milan 13- I5 September. Roma: Gangemi Editore.

Stirling Andy (2010). Keep it complex. In Nature, 468, pp. 1029-1031.

Wagner S. Caroline et al. (20I I). Approaches to understanding and measuring interdisciplinary scientific research (IDR): a review of the literature. In Journal of Informetrics, 5 ( I), pp. 14-26.

Author

Alessandro Luigini, Libera Università di Bolzano, alessandro.luigini@unibz.it

To cite this chapter. Luigini Alessandro (2020). Ricerca interdisciplinare e ICARI7: una proposta per la definizione di un modello condiviso/ Interdisciplinary research and ICAR 17: a proposal for the definition of a shared model. In Arena A., Arena M., Brandolino R.G., Colistra D., Ginex G., Mediati D., Nucifora S., Raffa P. (a cura di). Connettere. Un disegno per annodare e tessere. Atti del $42^{\circ}$ Convegno Internazionale dei Docenti delle Discipline della Rappresentazione/Connecting. Drawing for weaving relationships. Proceedings of the 42th International Conference of Representation Disciplines Teachers. Milano: FrancoAngeli, pp. 567-584. 